\title{
Knowledge Management Enablers, Process and Organizational Performance: Evidence from Malaysian Enterprises
}

\author{
Dr. Tan Thai Soon \\ TST Consulting Group Sdn Bhd \\ No. 5, Jalan 3/125D, Desa Petaling, 57100 Kuala Lumpur, Malaysia \\ E-mail: tanthaisoon@gmail.com
}

Dr. Fakhrul Anwar Zainol

Faculty of Business Management and Accountancy, Universiti Sultan Zainal Abidin (UniSZA)

21300 Kuala Terengganu, Terengganu, Malaysia

E-mail: fakhrulanwar@unisza.edu.my

Received: March 2, $2011 \quad$ Accepted: April 10, $2011 \quad$ doi:10.5539/ass.v7n8p186

\begin{abstract}
This research study demonstrates the important of the knowledge creation process. It helps to demonstrate that knowledge management enablers, including learning and T-Shaped skills can promote organizational creativity and thus organizational performance. Therefore it can be argued that the best path for Malaysian SMEs to achieve organizational performance is through organizational creativity achieved through a knowledge creation process that involves knowledge enablers. Further, the imperatives of globalization mean that it is generally accepted that it is imperative for business organizations, particularly SMEs, to improve their performance, through knowledge management, in what has become a global knowledge economy. In fact, this feature provides both the background to and the rationale for this study.
\end{abstract}

Keywords: Knowledge management enablers, Knowledge creation process, Organizational creativity, Organizational performance

\section{Background of the Study}

The growth in the importance of knowledge management in the modern world is evident, both in the development of new business knowledge management models by practitioners and professionals in so many companies and firms, and in the ever-growing academic literature. It is increasingly accepted today that a good understanding and the effective implementation of an appropriate knowledge management model have become a crucial part in achieving a company's long-term goals, such as efficiency and effectiveness in carrying out operations internally and achieve higher performance and competitiveness externally. With the globalization of the world economy, it is accepted by all that it is imperative for business organizations, wherever they are, to improve their performance, through knowledge management, in what has become a knowledge based economy, in order to survive, sustain and compete in the global environment. It follows that the employees of the organizations need to be more knowledgeable. In this respect, it can be seen as significant that, as early as 1967, Drucker identified the role of "knowledge workers" in the new society. According to Drucker (1992, p. 100) "every organization is in competition for its most essential resources; qualified, knowledgeable people." His view is echoed elsewhere in the literature.

According to Reich (1991; cited in Carter and Scarbrough, 2001, p. 217), "knowledge workers" are of a critical importance to an organization by virtue of:

- $\quad$ the importance of their knowledge and skills as a productive force for the organization;

- that they are viewed as constituting an investment for an organization rather than just being a labour cost;

- their personal embodied knowledge is such that it represents a form of personal equity and as such means that many knowledge workers are potential entrepreneurs. 
The importance of individual knowledge workers has been developed into the current theory of "knowledge management", and is therefore the main focus in the present study.

\section{Problem Statement}

The Malaysian enterprises that have been chosen as the field of study consist of Malaysian SMEs, drawn from two main categories. The first are those firms in the manufacturing, manufacturing-related services and agro-based industries with full-time employees not exceeding 150 or with an annual turnover not more than RM 25 million. The second are those firms in the services, primary agriculture and the information \& communication technology sector with full-time employees not more than 50 employees or with an annual turnover of not more than RM 5 million.

The crucial importance of SMEs to the performance of national economies is well-known. This research hopes to identify those factors in the knowledge creation process that can help Malaysian SMEs achieve organizational creativity and thus improved business performance. In turn, enhancing organizational creativity will enable firms to develop new products and services to compete with the same sector in emerging countries such as China, Vietnam and India.

The emergence of China as the world's leading manufacturing power house, especially, has posed new challenges to Malaysian SMEs in manufacturing. China is famous for its mass production with cheap and competitive products. This will require Malaysian SMEs to change from a traditional manufacturing management concept to a knowledge management concept, and to adapt their traditional management processes to knowledge creation processes. As a new phenomenon, the processes involved in this transition have been developed by Nonaka and his fellow writers in a "knowledge creation process model" ( Nonaka and Takeuchi, 1995; Nonaka, Umemoto and Senoo, 1996; Nonaka and Konno, 1998). Subsequent writers have carried out empirical research on the knowledge creation processes (Lee and Choi, 2003) and confirmed that "knowledge creation is positively related to organizational creativity, which is positively related with organization performance."

From such work, it is evident that the knowledge creation process can provide a platform for Malaysian SMEs to be creative and innovative. Creativity and innovation are the basis premises for the knowledge based economy. The early works in this area (Amabile, 1997; Woodman, Sawyer and Griffin, 1993) stressed that organizational creativity involves "the creation of a valuable, useful new product, service, idea, procedure, or process by individuals working together in a complex social system" (Woodman et al., 1993, p. 293). Some of the inspiration for such work came from observation of the progress of Japanese companies in the past half-century. According to Nonaka (1991) the success of the best Japanese companies offered a guide as to how the "knowledge-creating" company could produce continuous innovation (Nonaka, 1991). Certainly, they provide excellent examples of how, in order to be competitive in the global environment, Malaysian SMEs can transform their traditional methods to being creative and innovative. The process of developing creative industries may come from new bio-technology, new agro-based manufacturing process, new manufacturing process, new manufacture products, creative education system, and other new services. The important point here is that research into the knowledge creation process can stimulate and assist such changes.

This point is the more valid in the face of the emergence of India as the new ICT super power in the region. This already has prompted many Malaysian SMEs to change their strategic approach by incorporating information technology. The early evolution of information systems centred on the introduction of computer hardware and data processing into normal business practice (Nolan, 1979). However, as has already been emphasized, continuing advances in technology mean that there has since been a progression from mere data processing to information management. The current development of IT has transformed the information management to knowledge management (Davenport, 1997; Alavi and Leidner, 1999). A successful design of knowledge management programmes could help Malaysian SMEs to compete in the ICT, particularly where industry must be creative, example in animation products, products design, programming in manufacturing process and service sector, software products, but also, possibly, in the outsourcing sector.

To sum up, in order to be competitive and to improve organizational performance, Malaysian SMEs need to change to be more creative and innovative. This will require Malaysian SMEs to change from traditional forms of management, as has been characteristic of manufacturing, to a knowledge based conception. In the modern world it means a change from information management to knowledge management. In particular, in the world today, companies are moving from traditional management processes to knowledge creation processes. Malaysian SMEs must necessarily take part in this change. 
The research in this study has been designed to assist in such changes. It remains here to examine the development of knowledge management as a management concept and tool, in the process explaining why it can help Malaysian SMEs to achieve important national goals.

\section{Literature Review}

The concept of "Knowledge management" has been perhaps the most important phenomenon to emerge in recent years in the study of management. Knowledge management has been defined as the process involved in seeking to "understand, focus on, and manage systematic, explicit, and deliberate knowledge building, renewal, and application - that is, manage effective knowledge processes" (Wiig, 1997, p. 2). It is the process of "continually managing knowledge of all kinds to meet existing and emerging needs, to identify and exploit existing and acquired knowledge assets and to develop new opportunities" (Quintas, Lefrere and Jones, 1997, p. 387). The objective of developing a knowledge management model is to "create knowledge repositories; it attempts to improve knowledge access, and attempts to improve knowledge cultures and environments" (Davenport and Prusak, 1998, p. 146). Broadbent (1998, p. 24) indicates that "knowledge management is about enhancing the use of organizational knowledge through sound practices of information management and organizational learning." In short, knowledge management can be personal knowledge management or organizational knowledge management. The following section will categorize the development of knowledge management.

The rapid development of Information Technology in the late 1990s has accelerated the development of knowledge management, as can be seen from the works of many management writers (Sviokla, 1996; Nonaka, Umemoto and Senoo, 1996; Davenport, 1997; Alavi and Leidner, 1999). Information technology has been used as a knowledge creation tool (Nonaka et al., 1996); as a basis for information management ( Broadbent, 1998); for information systems (Alavi and Leidner, 1999); and for codification tools (Hansen, Nohria and Tierney, 1999). The development of information technology provides a new means for the subsequent development of information management into knowledge management. In short, knowledge management practitioners use information technology as a tool, a systems, data based and repository, and for information management It is all about "delivering information to support a task" and about "individual performance in the field" to get the job done (McElroy, 2000, p. 200). In this respect, it has been referred to as "first-generation KM" (McElroy, 2000, p. 200).

The next generation of knowledge management saw the management writers integrating the organizational learning and knowledge management (McElroy, 2000; Loermans, 2002; Firestone and McElroy, 2004). According to McElroy (2000, p. 199) "many practitioners of KM are now turning to the organizational learning (OL) community as a source for what it means for an organization to learn." In short, knowledge management writers try to integrate organizational learning into knowledge management. This development of knowledge management thus put the focus more on organization learning rather than on the individual in the workplace. This trend can be regarded as "second-generation KM" (McElroy, 2000, p. 199).

Current developments in knowledge management have seen many writers argue that knowledge management is best represented as "strategic knowledge management". Snyman and Kruger $(2004$, p. 17) have argued that knowledge management strategy should be an integral part of business strategy. With others, they argue that strategic knowledge management needs to be integrated with organizational performance in order to increase efficiency and thus the competitive advantage of firms. This development can be seen as deriving from the globalization of the world economy and the increased competitive nature of modern business.

However, generally, it is accepted that there is a "lack of strategic models to link KM efforts and business strategy" (Maier and Remus, 2002, p. 107) and that, very often, the knowledge management programmes, initiatives and activities that are developed "lack a strategic perspective" (Maier and Remus, 2002, p. 103). Other writers have called for more research into the relationship between knowledge management strategy and competitive advantage (Halawi, McCarthy and Aronson, 2006, p. 384). There is evidently much still to be done in an area that has changed rapidly in recent years. Other aspects relating to these relations are reviewed below but first, it may be instructive to review briefly the place of knowledge management in Malaysian SMEs.

There have always been many small enterprises in the Malaysian economy. However, official policy has long had its focus on large enterprises, especially in the late 1980s and early 1990s, as these were seen to be the key to rapid economic development. Indeed, the accepted definition of SME in Malaysia was only first approved by the National SME Development Council of Malaysia in 2005. This definition was subsequently adopted by various government agencies including the Small and Medium Industries Development Corporation (Smidec) to include the two main categories as follows:

a. Manufacturing, manufacturing-related services and agro-based industries with full-time employees not exceeding 150 or with annual sales turnover not exceeding RM 25 million. 
b. Services, primary agriculture and information \& communication technology (ICT) with full-time employees not exceeding 50 or annual sales turnover not exceeding RM 5 million.

The above two general categories can be further summarized into more detailed categories (Ndubisi and Saleh, 2006, p. 5) in Table 1. As will be evident, SMEs are distinguished from the Micro enterprises characteristic of a less developed economy.

Malaysian SMEs play an important role in the Malaysia economy in terms of economic growth and providing employment. They have become the prime mover and also the backbone of industrial development in Malaysia. Malaysian government had, in the late 1980s and early 1990s, been actively involved in promoting large-scale enterprises. Many of these projects ended in failure with losses of many billions of Malaysian Ringgit. Some writers argued that the "weakness of legal institutions for corporate governance" are the main causes of failure, as manifested during the Asia Financial Crisis in 1997 (Johnson, S., Boone, P., Breach, A. and Friedman, E., 2000, p. 142). Aziz, A. (1999, p. 118) argued "whilst external factors can be influential, they are only as strong as our internal weaknesses." Whatever the case, it would seem that one lesson learnt in the crisis was that the government should not become involved in too many commercial activities but rather focus on the setting up of policy and maintaining good business and social infrastructure, while ensuring that policies are efficiently implemented and effectively carried out. In recent years, it has tried to do this with reference to SMEs.

The Malaysian government is aware of the importance of SMEs and the importance of private investment enterprises. The setting up of Small and Medium Industries Development Corporation (SMIDEC) in 1996 was an early initiative by the Malaysian government to promote SMEs, while the Multimedia Super Corridor (MSC) in 1996 was developed with them very much in mind (see below). In a recent programme designed to promote the development of SMEs managers programmes, Deputy Human Resources Minister Datuk Noraini Ahmad said SMEs in Malaysia "contributing to $32 \%$ of the gross domestic product, accounted for $56.4 \%$ of the total workforce, contributing to 19\% of total exports" (News Straits Times, February 17, 2009; see also Fozian Ismail, 2008).

In general, the studies in the early 2000s showed a lack of knowledge management practice in private enterprises. An exploratory study by Badruddin (2004, p. 330) showed that the sort of organizations in general that were likely to undertake formal knowledge management initiatives were particularly in the "education sector, government-owned organizations and government departments". The private sector lagged in taking formal initiatives, even if some companies were slowly catching up. In a more recent study on the knowledge management in Malaysian MSC status companies, nine key "soft" knowledge management enablers were identified as important factors (Gerald Goh, Ryan and Gururajan, 2006, p. 8).

The study by Goh, Ryan and Gururajan is restricted and focused only on the Malaysian MSC status companies. In fact it can be said generally that there the low level of knowledge management practice in Malaysian SMEs is matched by a lack of study on knowledge management practice, and that no research has been conducted into knowledge management as part of an integrated approach. Further, it is evident that research findings from other regions and countries, for example the integrated knowledge management research on Australian SMEs conducted by Mohammad (2005), would not be directly applicable within the Malaysian environment. However, it is worth noting that three of the knowledge enablers (learning, T-Shaped skills and IT-support) that were part of this study were found to be positively related to the knowledge creation process (Mohammad 2005, p. 313). In addition, his study findings also confirmed a positive relationship between the knowledge creation process and organizational creativity, and between organizational creativity and organizational performance (Mohammad, 2005, p. 314).

Mohammed's work provides something of a model for this dissertation. There remains an evident need, which this study is intended to provide a basis for meeting, to investigate the extent to which knowledge enablers embracing the knowledge creation process have or can increase organizational creativity and ultimately organizational performance in Malaysian SMEs.

In view of the points made above, as to the general recognition of the importance of knowledge management, especially as part of a response to changes in the modern global economy, it is necessary now to review the "knowledge management enablers" that are embedded in a knowledge management process. The two main knowledge management enablers selected in this review include the two main aspects and dimensions in the organization, particularly in the SMEs setting. These two enablers involve a learning culture in the organization and people management skills. The two knowledge enablers chosen provide good dimensions; at the same time they are not too complex to handle in this research project setting involving SMEs.

Learning is an important factor in the knowledge creation process. Learning can involve processes that are either formal or informal, including such forms as discussion, brainstorming, seminars or online forums and through what can be termed the "community of practice". According to Robbins $(2005$, p. 48$)$ learning is "any relatively 
permanent change in behaviour that occurs as a result of experience." It involves "a change in behaviour" through "some form of experience", whether direct or indirect (Robbins, 2005, p. 49). Nonaka and Takeuchi (1995, p. 44) categorizes learning into two kinds of activity:

- The first kind of learning is obtaining know-how in order to solve specific problems based upon existing premises;

- The second kind of learning is establishing new premises, (that is, paradigms, schemata, mental models, or perspectives) to override the existing ones.

The traditional view of learning accepts that it is a critical basis for problem solving. One particularly valuable approach that reflects this view has come from Argyris, who has developed the concept of "double-loop learning" (Argyris, 1977, p. 114) in a series of papers and studies. According to Argyris (1995, p. 20) learning occurs whenever errors are corrected, either through "change the behavior" (single-loop learning) or "change the underlying programme or master programme" (double-loop learning) (Argyris and Schon, 1974; Argyris, 1995 , p. 20). The concepts help in illuminating how people think and the nature of their cognitive reasoning (Argyris, 1991, p. 100). According to Argyris (1995, p. 20) for learning to be effective, an individual must "change the behavior" while "changing the master programmes" that individuals use to produce actions. The nature of the learning process and the nature of "change behavior" by individual and employees in an organization is of critical importance in terms of the ability of an organization to change and to be creative, as a basis for continuous improvement and thus sustainable performance.

Management writers have thus long recognized the importance of continuous learning in building a "learning organization". An early work in this area was by Senge's (1990a), with the title "The fifth discipline"; this provided themes that formed the foundation of the concept of the "learning organization". In his subsequent work, Senge described how "new roles, skills, and tools" had to be developed for leaders who wished to develop a learning organization (Senge, 1990b, p. 7). His model was based on Japanese practice. According to Senge (1992) "many Japanese companies have institutionalized learning around quality improvement teams and related innovation". Much could be learnt from these. Senge (1999, p. 38) provides some guides to develop an organization's capabilities in learning organization:

- Building shared vision - there is no substitute for organizational resolve, conviction, commitment, and clarity of intent. They create the need for learning and the collective will to learn. Without shared visions, significant learning occurs only when there are crisis;

- $\quad$ Personal mastery - an organization that is continually learning how to create its future must be made up of individuals who are continually learning how to create more of what truly matters to them;

- Working with mental models - organizations become frozen in inaccurate and disempowering views of reality because they lack the capability to see their assumptions and to continually challenge and improve them;

- Team learning - ultimately, the learning that matters is the learning of groups of people who need one another to act (the real meaning of team; and

- Systems thinking - it's not just how we learn, but what we learn. The most important learning in contemporary organizations concerns gaining shared insight into complexity and how we can shape change.

According to Huber (1991, p. 89) an entity learns, "if through its processing of information, the range of its potential behaviors is changed." At the same time, it should be emphasized that there is no standard operational definition of "organizational learning". It can be linked to "knowledge acquisition, information distribution, information interpretation, and organizational memory" (Huber, 1991, p. 88); it can also be approached as an organizational skills that can be utilized in "creating, acquiring, and transferring knowledge, and at modifying its behavior to reflect new knowledge and insights" (Garvin, 1993, p. 80).

From organizational learning to knowledge management, other management theorists have stressed the possibilities arising from the integration of complexity theory and knowledge management into organizational learning. Thus McElroy, (2000, p. 195) expresses the theme: "KM now regards OL as its new best friend." In addition, some authors have argued that "organizational learning" is not only about processing information, but also about helping to "create information and knowledge" (Nonaka, Byosiere, Borucki and Konno, 1994, p. 338). Further, by "embedding learning" companies can "improve the consistency and effectiveness of knowledge use throughout an organization" (Cross and Baird, 2000, p. 69). 
The concept of "people" is another important construct in knowledge management. It is generally agreed that the brain of the people in an organization has an unlimited capacity for information and knowledge, whether this is tacit or explicit. Leonard and Straus (1997, p. 109) argue that the whole company brain can be put to work and suggest ways and processes to achieve this. They distinguish between what they call "the comfortable clone syndrome" and the "creative abrasion" that propels innovation. In particularly, they argue, "to innovate successfully, you must hire, work with, and promote people who are unlike you" (Leonard and Straus, 1997, p. 117).

Such approaches may not suit all managers or all organizations. However, it can be accepted that, while people brain power may be unlimited, to be beneficial to the organization, the right skills for creativity must be employed. In this respect, Hansen and Oetinger (2001, p. 107) introduced the concept of "T-Shaped" managers, who are willing to share knowledge freely across the organization. The term "T-Shaped" refers to the behaviour of managers who are more flexible in sharing knowledge freely, learning and collaborating across the business units - this is the horizontal part of the $\mathrm{T}$ (Hansen and Oetinger, 2001, p. 108). They are thus managers who are willing to share knowledge freely across the organization.

Knowledge creation can come from different entities and in different forms and types. The main platform of knowledge creation is the "phenomenal" place. Knowledge creation can emerge from "individuals, working groups, project teams, informal circles, temporary meetings, e-mail groups, and at the front-line contact with the customer" (Nonaka and Konno, 1998, p. 41). It can also come from the "communities of interaction" where "social interaction between individuals" gives rise to the sharing and development of new knowledge (Nonaka, 1994, p. 15). Subsequent writers also agreed that community of practice is a source of knowledge creation, as they put it "the purpose of the community is to ensure that professionals collaborate across plants, geographical boundaries, and sometimes also functional boundaries. Such communities of practice have already led to a number of significant benefits in Unilever."

Similarly, the knowledge creation may come from the "knowledge activist", who can be "someone, some group or department ... coordinating knowledge creation efforts throughout the corporation" (Krogh, Nonaka and Ichijo, 1997, p. 475). A knowledge activist formulates "process triggers and creates space or context for knowledge creation", and he or she "acts in three roles: as a catalyst of knowledge creation, as a connector of knowledge creation initiatives and as a merchant of foresight." (Krogh et al., 1997, p. 475). Salisbury (2001, p. 305) provides an example of managing the knowledge creation process for a small work group, where "a knowledge base is used for capturing the expertise of individuals and making it available to other members of the group." A more recent study also reveals that "interaction processes permitting the creation of knowledge in small hi-tech firms can take place via: formal meetings, informal communities, project teams, external interaction; and information technology tools." (Spraggon and Bodolica, 2008, p. 879). It can be argued that the current developments in internet and social media, such as Yahoo! Group and Facebook, represent a new phenomenon of knowledge creation, although this must be subject to further empirical study, where members of the group are able to communicate and interact with each other through online media tools and email.

On the other hand, organizational creativity lies at the heart of the knowledge creative process. Many works, from writers such as Amabile, Conti, Coon, Lazenby, and Herron (1996); Amabile (1997) and Woodman, Sawyer and Griffin (1993), have emphasized this relationship. While there is no standard definition of creativity or organizational creativity, two attempts have been found of value here. Creativity has been defined as "the production of novel and useful ideas in any domain" (Amabile et al., 1996, p. 1155). According to Amabile et al. (1996, p. 1155) "creativity is the seed of all innovation, and psychological perceptions of innovation (the implementation of people's ideas) within an organization are likely to impact the motivation to generate new ideals." The meaning of creativity may include creativity from an individual, within and outside of an organization, or from sources in society at large.

Management writers have adapted the meaning of "creativity" to the context of the operations of an organization. According to Woodman et al. (1993, p. 293) "organizational creativity is the creation of a valuable, useful new product, service, idea, procedure, or process by individuals working together in a complex social systems." This can be taken as an operational definition for an examination of organizational creativity.

It is necessary to be able to see what can and has been achieved through promoting organizational creativity, innovation, etc., and this is best done through measuring "organizational performance". Organizational performance can be measured in various ways, as in terms of profitability, growth rate, market share or even competitive advantage. Lee and Choi (2003, p.190) categorize methods for measuring organizational performance 
in knowledge management that include "financial measures, intellectual capital, tangible and intangible benefits, and balanced scorecard."

\section{Theoretical Framework, Research Question and Hypothesis}

4.1 Theoretical Framework

\section{Insert Figure 1 Here}

4.2 Research Question

Research questions are constructed in order to meet the objectives of the research:

1. What is the relationship between knowledge management enablers and the knowledge creation process?

2. Is organizational creativity linked to the knowledge creation process?

3. Is organizational creativity linked to organizational performance?

\subsection{Hypothesis}

In order to answer the abovementioned research question, this study posits the hypothesis to be:

H1: Learning is positively related to the knowledge creation process

H2: T-Shaped skills are positively related to the knowledge creation process.

H3: The knowledge creation process is positively related to organizational creativity.

H4: Organizational creativity is positively related to organizational performance.

\section{Research Design and Methodology}

The sampling method having been decided on, it remains to explain the manner of approach to the units that are the subject of analysis. These units have been taken from Malaysian SMEs which can be categorized into two sections. The first category includes companies in manufacturing, manufacturing related services and agro-based industries, with full-time employees not exceeding 150, or annual turnover not exceeding RM 25 million. The second category includes companies in services, primary agriculture and information and communication technology (ICT) with full-time employees not exceeding 50, or annual turnover not exceeding RM 5 million.

An information statement relating to the nature of this study together with the questionnaire was sent to the management of a number of companies, which were within the categories set out above and listed in Malaysian SME business directories on a random basis. It was taken that those who replied to the invitation, which allowed them to remain anonymous, had given informed consent.

According to Chin (1998) the number of responses required for the questionnaires should be at least 10 times the number of items in the largest scale. Based on the questionnaire, a minimum of 50 responses was required as the number of items in the largest scale is 5 . Based on an anticipated response rate of 5\%, a total of about 1025 letters of invitation to participate in the survey, together with the above documents, were sent to Malaysian SMEs that fell into the two categories outlined above.

\section{Results}

\subsection{Descriptive Analysis}

A total of 1025 questionnaires were distributed to Malaysian SMEs organizations. These were organizations randomly selected from Malaysian SMEs directories. Each organization was sent a survey questionnaire that invited the owners or the managers in the organization to participate in the research. Out of the total number distributed, 110 of questionnaires were returned. Out of the total that responded, 5 questionnaires were incomplete, therefore only 105 questionnaires were used in the data analysis. This amounted to a $10.24 \%$ response rate.

The composition of the sample indicates that the majority of the respondents are male with $70.5 \%$ as against female with $29.5 \%$. This composition was not unexpected as it is reasonable to see a relatively high number of females in management positions in Malaysian companies. Malaysian females have benefited from official programmes of equal opportunity in education and employment in Malaysia, and many of them hold such management positions as chief operating officers, administration managers and human resource managers. In addition, many females have become entrepreneurs in the service sector.

As for work experience, respondents with less than 5 years comprised of $13.3 \%$ of the total number; those with work experience between 5 years to 10 years comprised 24.8\%; those with work experience between 11 years to 15 years comprised $23.8 \%$; and those work experience with 16 years and above comprised $38.1 \%$. Thus the results showed that $61.9 \%$ of respondents had more than 10 years working experience. Only $13.3 \%$ of the respondents had 
less than 5 years experience, and these are perhaps the young entrepreneurs in the services and ICT sectors. Based on the length of working experience of more than 10 years, it may be presumed that more than half of the respondents are either owners of partners or shareholders in the organizations.

As regards to the education qualification, the respondents' distribution indicates that $21.9 \%$ have only a diploma or a lesser or no qualification, $33.3 \%$ have a bachelor's degree and $32.4 \%$ have a post graduate degree and above. Further, $12.4 \%$ have attained a professional degree. The results indicate $78.1 \%$ of the respondents have at least attained a tertiary qualification. The changes in Malaysian education policy and the development of knowledge management in the last decade may have contributed to the high level of education in Malaysian entrepreneurs and management personnel that is indicated in this sample.

\subsection{Reliability Analysis}

Reliability analysis measures the stability and consistency of the concept and helps to assess the "goodness of a measure" (Sekaran, 1992, p. 173). Consistency indicates how well the items "hang together as a set" (Sekaran, 1992, p. 174). One of the consistency tests is inter-item consistency reliability, and this is best achieved by using Cronbach's coefficient alpha. Cronbach's alpha indicates "how well the items in a set are positively correlated to one another" (Cavana et al., 2001, p. 321).

Table 2 tabulated all the internal reliabilities of the scales by using Cronbach's alpha $(\alpha)$, which measures the reliability of a research instrument in social science, to examine the internal consistency of the research instrument. It is generally considered that for Cronbach's alpha, 0.8 and above are very good, between 0.7 and 0.8 are considered good, and those between 0.6 and 0.7 are adequate. Results for Cronbach's alpha below 0.6 are consider poor and therefore should be deleted. Hence, as the internal validity for all the constructs is at least 0.6 and above, therefore the entire constructs are acceptable.

\section{Factor Analysis for the Knowledge Management Enablers}

Table 3 indicates the loading factor for learning. The scale shows a loading factor of above the cut-off level of 0.4 and is therefore accepted. The variable LEA2, which was dropped in the reliability test above, has not been included.

Table 4 shows that all the factor values taken from the component matrix are above the 0.4 cut off point level, therefore all are accepted.

\section{Factor Analysis for Knowledge Creation Process}

Table 5 presents the loading factor of knowledge creation process. Since all the variables are above the cut-off point of 0.4 , therefore they are accepted.

\section{Factor Analysis for Organizational Creativity}

Table 6 presents the loading factors for organizational creativity. The entire scale factor loadings have achieved the cut-off level, therefore all are accepted.

\section{Factor Analysis for Organizational Performance}

The loading factor of organization performance, the dependent construct, is presented in the table 7 . The entire scale factor loading have achieved the cut-off level of 0.4 , therefore all the scale is accepted.

\subsection{Results of Regression}

The results of running regression analysis for Learning vs. the knowledge creation process are summarized in table 8. As the table shows $\mathrm{P}=0.01<0.5$, hypothesis $\mathrm{H} 1$ is supported and it can be concluded that learning (the independent variable) significantly affects the knowledge creation process (the dependent variable). In addition, as the B-value is +0.462 , it can be concluded that there is a significant and positive relationship between learning and the knowledge creation process. Also, learning explains $21.3 \%$ of the total variance (R2) in the knowledge creation process, and this strength is considered between medium and large based on the benchmark $(\mathrm{R} 2=0.01=$ small, $0.05=$ medium, $0.25=$ large) set by Cohen (1992).

In addition, the results of regression for T-Shaped skills vs. The knowledge creation process are summarized in the table 9. As the table shows that $\mathrm{P}=0.01<0.5$, the hypothesis $\mathrm{H} 2$ is supported and it can be concluded that T-Shaped skills (independent variable) significantly affect the knowledge creation process (dependent variable). In addition, since the B-value is +0.552 , it can be concluded that there is a significant and positive relationship between T-Shaped skills and the knowledge creation process. Also, T-Shaped skills explain $30.4 \%$ of the total variance (R2) in the knowledge creation process. This strength is considered large based on the benchmark $(\mathrm{R} 2=0.01=$ small, $0.05=$ medium, $0.25=$ large) set by Cohen (1992). 
For the knowledge creation process $(\mathrm{KCP})$ vs. organizational creativity $(\mathrm{OC})$ the table 10 shows $\mathrm{P}=0.01<0.5$, and thus the hypothesis $\mathrm{H} 3$ is supported. It can be concluded that the knowledge creation process (independent variable) significantly affects organizational creativity (dependent variable). In addition, since B-value is +0.544 , it can be concluded that there is a significant and positive relationship between knowledge creation process and organizational creativity. Also, the knowledge creation process explains $29.6 \%$ of the total variance (R2) in the organizational creativity, and this strength is considered large based on the benchmark $(\mathrm{R} 2=0.01=$ small, $0.05=$ medium, $0.25=$ large) set by Cohen (1992).

The result for Organizational Creativity (OC) vs. Organizational Performance (OP) in table 11 shows that $\mathrm{P}=0.01$ $<0.5$, and thus the hypothesis $\mathrm{H} 4$ is supported. It can be concluded that organizational creativity (independent variable) significantly affects the organizational performance (dependent variable). In addition, since B-value is +0.578 , it can be concluded that there is a significant and positive relationship between organizational creativity and organizational performance. Also, organizational creativity explains $33.4 \%$ of the total variance (R2) in the organizational performance, and this strength can be considered large based on the benchmark $(\mathrm{R} 2=0.01=$ small, $0.05=$ medium, $0.25=$ large) set by Cohen (1992).

\section{Discussion}

Learning (H1) has been supported as positively related to the knowledge creation process. This is entirely consistent with the leading academic authorities on knowledge management. Thus, according to Argyris, learning means to "change behavior" (Argyris, 1995; see also McElroy, 2000) and it involves "knowledge acquisition, information distribution, information interpretation, and organizational memory" (Huber, 1999). As Nonaka and Takeuchi (1995) also emphasize, learning is therefore central to the knowledge creation process.

The research results in this study provide empirical support for the importance of the link between learning and the knowledge creation process. In view of the theoretical limitations of this study, caution has to be applied in relating this finding to the particular case of Malaysian organizations. However, it could be argued that there are promising implications. Thus learning has always played an important role in Malaysian society while public policy has stressed the importance of education in the past 15 years. The encouragement given to the establishment of many private higher education institutions (local and foreign), has been an important factor in human resource development in Malaysia, and has had a strong influence on the SME sector.

Another factor associated with learning, with a positive impact on knowledge creation, in Malaysia, is the development of internet technology. This has enabled the rapid growth of such organizational features as social networking sites, forums and groups based on community of practice and open sourcing. It is difficult to exaggerate the importance of their potential role in informal learning and the knowledge creation process in Malaysian SMEs.

The existence of T-Shaped skills (H2) has also been found, in this study, to be positively related to the knowledge creation process. Again, this is consistent with the academic literature on the knowledge creation processes. Thus, according to Leonard and Straus (1997) it is advantageous to "hire, work with, and promote people who are unlike you". T-Shaped skills, it is argued, relate to and arise out of the "degree of understanding his or her own and others' task areas" (Lee and Choi, 2003).

It is interesting to consider how far such features can be related to the nature of Malaysian SMEs, thus promoting their effectiveness in knowledge creation. Malaysian SMEs are generally owned by individuals or as family enterprises. Their organization is generally less formal and without rigid structures. Communications between the various parts of the firm, and between individuals in the same and in different departments is frequent and effective, especially as it is not unusual for employees at various levels to be willing and able to multi-task across different departments. It follows that such employees in SMEs are used to frequent interaction, are able to communicate with and understand the task areas of others. Indeed it is frequently necessary that they are interdependent in the interest of the organization's survival let alone growth. The potential for knowledge creation on the basis of such skills in Malaysian SMEs is thus evident.

This study shows that the knowledge creation process is positively related to organizational creativity. The hypothesis (H3) has been supported. As Nonaka and Takeushi put it, the knowledge creation process and indeed the whole organizational knowledge creation process is important because this relates to "the capability of a company as a whole to create new knowledge, disseminate it throughout the organization, and embody it in products, services, and systems" (Nonaka and Takeuchi, 1995, p. 3). This enables the "knowledge creating" company to achieve continuous innovation (Nonaka, 1991, p. 96). 
It follows that the process in the knowledge creation company will lead to organizational creativity. Creativity has been defined as "the production of novel and useful ideas in any domain" (Amabile et al., 1996, p. 1155), and organizational creativity as "the creation of a valuable, useful new product, service, idea, procedure, or process by individuals working together in a complex social systems" (Woodman et al., 1993, p. 293). It follows that such processes are potentially important to Malaysian SMEs.

This research study has found that the organizational creativity is positively related to organizational performance. The hypothesis (H4) has been supported. Organizational performance according to Lee and Choi (2003, p. 222), can be assessed through the "overall success, market share, growth rate, profitability, and innovativeness". In the case of Malaysian SMEs, there is some evidence of change and improvement during the last decade. It is evident from this study that their capacity to play an important part in the economy rests on their commitment to knowledge management. It is hoped that this study will provide support for encouraging public policy to pursue such trends.

It has to be stressed that any implications from this study for public policy can only be limited. Although all the hypotheses tested in the study were positive, no attempt was made to measure the inter-relationships and thus the relative importance of the variables in the model. The four knowledge management enablers are certainly linked to the knowledge creation process, to organizational creativity and organizational performance. However, it is impossible to say anything further in analysis on the basis of this study.

\section{Conclusion}

While all the hypotheses tested were supported, it is doubtful whether any policy implications can derive from this study without a more sophisticated approach examining the interactions between the variables.

However, the study did investigate an integrated view of knowledge management enablers, organizational creativity and organizational performance, based on the example set by Lee and Choi (2003, p. 222), who wished to assess "overall success, market share, growth rate, profitability, and innovativeness". Their measure retained a "financial performance" perspective of balanced scorecard and "supplements it with measures on the drivers of future potential" (Lee and Choi, 2003, p. 190). This measure may have its limitation in the competitive globalized economic environment but it provides a starting-point for policy initiatives.

Thus, in the changing global economic landscape, emerging countries, like Malaysia, face many challenges to their manufacturing sector. It follows that its firms, including Malaysian SMEs, must look to high-technology, high-knowledge skills and high-capital intensive industries. Only in this fashion will they be able to achieve a sustained competitive advantage, with a basis in resources like "value, rareness, imitability, and substitutability" (Barney, 1991, p. 99). As proposed by Halawi et al., (2006, p. 384) "future research should investigate the circumstances under which knowledge management can create a sustainable competitive advantage within the framework of the resource-based view (RBV)". It is therefore recommended that the future research on Malaysian SMEs should further investigate the relationship between knowledge management and competitive advantage.

\section{References}

Ackoff, R.L. (1989). From data to wisdom. Journal of Applied Systems Analysis, Vol. 16, pp. 3-9.

Alavi, M. \& Leidner, D. (1999). Knowledge management systems: emerging views \& practices from the field. Communications of the AIS, February.

Alavi, M. \& Leidner, D. (2001). Review: Knowledge management \& knowledge management systems: Conceptual foundations \& research issues. Management Information systems Research Center, Vol. 25, 1, pp. 107-135.

Amabile, T.M., Conti, R., Coon, H., Lazenby, J. \& Herron, M. (1996). Assessing the work environment for creativity. Academy of Management Journal, Vol. 39, 5, pp. 1154-1184.

Amabile, T.M. (1997). Motivating creativity in organizations: on doing what you love \& loving what you do. California Management Review, Vol. 40, 1, pp. 39-58.

Amaratunga, D. \& Baldry, D. (2002). Moving from performance measurement to performance management. Facilities, Vol. 20, 5/6, pp. 217-223.

Amaratunga, D., Baldry, D., Sarshar, M. \& Newton, R. (2002). Quantitative \& qualitative research in the built environment: application of "mixed" research approach. Work Study, Vol. 51, 1, pp. 17-31.

Argyris, C. \& Schon, D. (1974). Theory in practice. Jossey Bass. 
Argyris, C. (1977). Organizational learning \& management information systems. Accounting, Organizations \& Society, Vol. 2, 2, pp. 113-123.

Argyris, C. (1991). Teaching smart people how to learn. Harvard Business Review, May-June, pp. 99-109.

Argyris, C. (1995). Action science \& organizational learning. Journal of Managerial Psychology, Vol. 10, 6, pp. 20-26.

Ayer, A. J. (1956) .The Problem of Knowledge. Penguin Books Ltd.

Aziz, A. (1999). Managing risks for Asia's post-crisis environment, In S.H. Abdullah \& K.S. Sieh (Eds) Tunku Abdul Aziz, Fighting Corruption: My Mission. Konrad Adenauer Foundation, pp. 113-118.

Badruddin, A. R. (2004). Knowledge Management Initiatives: Exploratory Study in Malaysia. The Journal of American Academy of Business, March, pp. 330-335.

Bank Negara Malaysia. (2000). Malaysia Enterprise, accessed April 1. [Online] Available: http://www.bnm.gov.my.

Barney, J.B. (1991). Firm resources \& sustained competitive advantage. Journal of Management, Vol. 17, 1, pp. 99-120.

Barney, J.B. (1995). Looking inside for competitive advantage. Academy of Management Executive, Vol. 9, 4, pp. 49-61.

Bellinger, G., Castro, D. \& Mills, A. (2004). Data, Information, Knowledge, \& Wisdom. [Online] Available: http://www.systems-thinking.org/dikw.htm, (April 20, 2007), pp. 1-5.

Botten, N. \& Sims, A. (2005). Management Accounting Business Strategy, CIMA Publishing, Oxford.

Bourne, M. (2005). Better performance measurement. New Straits Times, January, 15.

Broadbent, M. (1998). The phenomenon of knowledge management: What does it mean to the information. Information Outlook, May, pp. 23-36.

Bryman, A. (2008). Social Research Methods. Oxford University Press, New York.

Brynjolfsson, E. \& Hitt, L.M (1998). Beyond the productivity paradox. Communications of the ACM, Vol. 41, 8, pp. 49-55.

Burrell, G. \& Morgan, G. (1979). Sociological paradigms \& organizational analysis: elements of the sociology of corporate life, part I, Chapter 1-3, pp. 1-37. Heinemann.

Carter, C. \& Scarbrough, H. (2001). Towards a second generation of KM? The people management challenge. Education \& Training, Vol. 43, 4/5, pp. 215-224.

Cavana, R.Y., Delahaye, B.L. \& Sekaran, U. (2001). Applied business research: Qualitative \& quantitative methods. John Wiley \& Son, Milton.

Chin, W. W. (1998). The partial least squares approach to structural equation modeling. In G. A. Marcoulides (Ed.) Modern methods for business research. Lawrence Erlbaum Associates, pp.295-336.

Cohen, J. (1992). Quantitative Methods in Psychology, A Power Primer. Psychological Bulletin, Vol. 112, 1, pp. 155-159.

Coyne, K.P. (1986). Sustainable Competitive Advantage - What it is, what it isn't. Business Horizon, Jan-Feb, pp. 54-61.

Ch\&ler, A.D. (1963). Strategy \& structure. Cambridge, MA: MIT Press.

Cross, R. \& Baird, L. (2000). Technology is not enough: Improving performance by building Organizational Memory. Sloan Management Review, Spring, pp.69-78.

Cyert, R.M. \& March, J.G. (1963). A behavioral theory of the firm. Prentice Hall.

Davenport, T.H. (1997). Some Principles of Knowledge Management. Working Paper.

Davenport, T.H. \& Prusak, L. (1998). Working Knowledge: How organizations manage what they know. Harvard Business School Press, Boston.

Davenport, T.H., De Long, D. W. \& Beers, M.C. (1998). Successful knowledge management projects. Sloan Management Review, Vol. 39, 2, pp. 43-57. 
Deshp\&e, R., Jarley, U. \& Webster, F. (1993). Corporate culture, customer orientation, \& innovativeness in Japanese firms: A quadrad analysis. Journal of Marketing, Vol. 57, 1, pp. 23-37

Draper, A.K. (2004). Workshop on 'Developing qualitative research method skills: analyzing \& applying your results' The principles \& application of qualitative research. Proceedings of the Nutrition Society, Vol. 63, pp. 641-646.

Drew, S. (1997). From knowledge to action: The impact of benchmarking on organizational performance. Long Range Planning, Vol. 30, 3, pp. 427-441.

Drucker, P.F. (1974). Management: Tasks, Responsibilities, Practices. Harper \& Row, New York.

Drucker, P.F. (1992). The New Society of Organizations. Harvard Business Review, Sept-Oct, pp. 95-104.

Drucker, P.F. (1993). Post-Capitalist Society. Harper Collins, New York.

Eccles, R.J. (1991). The performance measurement manifesto. Harvard Business Review, January-February.

Fahey, L. \& Prusak, L. (1998). The eleven deadliest sins of knowledge management. California Management Review, Vol. 40, 3, pp. 265-276.

Firestone, J. M. \& McElroy, M.W. (2004). Viewpoint Organizational Learning \& Knowledge management: the relationship. The Learning Organization, Vol. 11, 2, pp.177-184.

Fozian Ismail (2008). Developing Innovation-Led \& Technology-Driven SMEs, Klang Valley investment \& trade dialogue \& seminar on the manufacturing \& services sectors. Putra World Trade Centre, Kuala Lumpur, 28 \& 29 January, 2008.

Garvin, D. A. (1993). Building a learning organization. Harvard Business Review, pp. 78-91.

Gay, L.R. \& Diehl, P.L. (1992). Research Methods for Business \& Management. Macmillan Publishing Company: New York.

Gerald Goh, G.G., Ryan, C. \& Gururajan, R. (2006). Soft enablers of knowledge management in Malaysian companies-a qualitative study, $17^{\text {th }}$ Australasian Coference on Information Systems. University of Southern Queens1\&, pp. 1-12

Ghemawat, P. (2001). Strategy \& the business l\&scape. Prentice Hall: New Jersey.

Glueck, W.F. (1980). Business policy \& strategic management ( $3^{\text {rd }}$ edition). McGraw-Hill: New York.

Godbout, A. J. (1999). Filtering knowledge: changing information into knowledge assets. Journal of systemic knowledge Management, January.

Goldman, A. I. (1999). Knowledge in a Social World. Oxford Univ. Press: New York

Gomes, C. E., Yasin, M.M. \& Lisboa, J.V. (2004). A literature review of manufacturing performance measures \& measurement in an organizational context: a framework \& direction for future research. Journal of Manufacturing Technology Management, Vol. 15, 6, pp. 511-530.

Grant, R. M. (1996). Toward a knowledge-based theory of the firm. Strategic Management Journal, Vol.17, pp.109-122.

Guiriek, J.C. \& Thoreau, A. (1984). Planification et Communication: I experience d' Air France. Revue Francaise de Gestion., pp. 135-139.

Hair, J.F., Black, W. C., Babin, B. J. \& \&erson, R. E. (2010). Multivariate Data Analysis, A Global Perspective ( $7^{\text {th }}$ edition). Person Prentice Hall: New Jersey.

Halawi, L.A., McCarthy, R.V. \& Aronson, J.E. (2006). Knowledge management \& the competitive strategy of the firm. The Learning Organization, Vol. 13, 4, pp. 384-397.

Hansen, M. T., Nohria, N. \& Tierney, T. (1999). What's your strategy for managing knowledge? Harvard Business Review, pp. 106-116.

Hansen, M.T. \& Oetinger, B. (2001). Introducing T-shaped Managers, Knowledge Management's Next Generation. Harvard Business Review, March, pp. 107-116.

Heron, J. \& Reason, P. (1997). A participatory inquiry paradigm. Qualitative Inquiry, Vol. 3, 3, pp. 274-294.

Huber, G.P. (1991). Organizational Learning: The contributing processes \& the literatures. Organization Science, Vol. 2, 1, pp. 88-115. 
Hussey, J. \& Hussey, R. (1997). Business Research, A practical guide for undergraduate \& postgraduate students. Palgrave: New York.

Hussin, S. (1995). Art of Research \& Dissertation Writing. Asas Tunas Publications: Malaysia.

Johnson-Laird. (1983). Mental Models. Cambridge University Press: Cambridge.

Johnson, S., Boone, P., Breach, A. \& Friedman, E. (2000). Corporate governance in the Asian financial crisis. Journal of Financial Economics, Vol. 58, pp.141-186.

Kaplan, R.S. (1983). Measuring manufacturing performance: a new challenge for managerial accounting research. Accounting Review, Vol. 58, 4, pp.686-703.

Kaplan, R. S. \& Norton, D. P. (1992). The Balanced Scorecard-Measures that drive performance. Harvard Business Review, Jan-Feb, pp. 71-79.

Kaplan, R.S. \& Norton, D.P. (1996). Using the balance scorecard as a strategic management system. Harvard Business Review, Jan-Feb, pp.75-85.

Kaplan, R.S. \& Norton, D.P. (2001). Transforming the balance scorecard from performance measurement to strategic management: part I. Accounting Horizons, Vol. 15, 1, pp. 87-104.

Krogh, G. V., Nonaka, I. \& Ichijo, K. (1997). Develop Knowledge Activists. European Management Journal, Vol. 15,5 , pp. 475-483.

Lee, H. \& Choi, B. (2003). Knowledge management enablers, processes, \& organizational performance : An integrative view \& empirical examination. Journal of Management Information systems, Vol. 20, 1, pp. 179-228.

Leonard, D. \& Straus, S. (1997). Putting your company's whole brain to work, (Ed) in Harvard Business Review on knowledge management. Harvard Business Review, Boston.

Liao, S. H. (2003). Knowledge management technologies \& applications-literature review from 1995 to 2002. Expert Systems with Applications, Vol. 25, pp. 155-164.

Loermans, J. (2002). Synergizing the learning organization \& knowledge management. Journal of Knowledge Management, Vol. 6, 3, pp. 285-294.

Maier, R. \& Remus, U. (2002). Defining process-oriented knowledge management strategies. Knowledge \& Process Management, Vol. 9, 2, pp. 103-118.

Malhotra, N.K. (2003). Marketing Research: An Applied Orientation, ( $4^{\text {th }}$ edition). International Edition.

McElroy, M.W. (2000). Integrating complexity theory, knowledge management \& organizational learning. Journal of Knowledge Management, Vol. 4, 3, pp. 195-203.

Mintzberg, H. (1987). The Strategy Concept I: Five Ps For Strategy. California Management Review, Vol. 30, pp.11-24.

Mintzberg, H. (1994). The rise \& fall of strategic planning: reconceiving roles for planning, plans, planners. The Free Press, New York.

Ministry of Finance Malaysia (2009). Economic Report 2009/2010, Malaysia.

Mohammad, M. (2005). An Integrative View \& Empirical Examination of the Relationships among Knowledge Management Enablers, Processes, \& Organizational Performance in Australian Enterprises, Doctor of Philosophy thesis, University of Wollongong, Australia.

MSC Malaysia. (2009). About MSC Malaysia, Vision \& Mission. [Online] Available: http://www.mscmalaysia.my/topic/1273014710796 (July 20, 2009)

National SME Development Council. (2005). Definitions for Small \& Medium Enterprises in Malaysia, 9 June 2005, pp.1-7.

Ndubisi, N. O. \& Saleh, A. S. (Eds.) (2006). Small \& Medium Enterprises (SMEs) Malaysian \& Global Perspectives. Person Prentice Hall:Malaysia.

News Straits Times. (2009). Giving managers the right skills, February 17.

Nolan, R.L. (1979). Managing the crisis in data processing. Harvard Business Review, Mar-Apr., pp. 115-126.

Nonaka, I. (1991). The Knowledge-Creating Company. Harvard Business Review, 11-12, pp. 96-104.

Nonaka, I. (1994). A Dynamic Theory of Organizational Knowledge Creation. Organization Science, Vol. 5, 1, pp.14-37. 
Nonaka, I., Byosiere, P., Borucki, C.C. \& Konno, N. (1994). Organizational knowledge creation theory: a first comprehensive test. International Business Review, Vol. 3, 4, pp.337-351.

Nonaka, I \& Takeuchi, H. (1995). The knowledge-creation company: how Japanese companies create the dynamics of innovation. Oxford University Press, New York.

Nonaka, I., Umemoto, K. \& Senoo, D. (1996). From information processing to knowledge creation: A paradigm shift in business management. Technology in society, Vol. 18, 2, pp. 203-218

Nonaka, I. \& Konno, N. (1998). The Concept of "Ba": Building A Foundation For Knowledge Creation. California Management Review, Vol.40, 3, pp. 40-54.

Nonaka, I., Toyama, R. \& Konno, N. (2000). SECI, Ba \& Leadership: a Unified Model of Dynamic Knowledge Creation. Long Range Planning, Vol.33, pp. 5-34.

Nonaka, I \& Toyama, R. (2003). The knowledge-creating theory revisited: knowledge creation as a synthesizing process. Knowledge Management Research \& Practice, 1, pp. 2-10.

Peteraf, M.A. (1993). The cornerstones of competitive advantage: A resource-based view. Strategic Management Journal, Vol. 14, 3, pp. 179- 191.

Polanyi, M. (1966). The Tacit Dimension. Routledge \& Kegan Paul, London.

Prasad, A. \& Prasad, P. (2002). The coming of age of interpretive organizational research. Organizational Research Methods, Vol. 5, 1, pp. 4-11.

Quintas, P., Lefrere, P. \& Jones, G. (1997). Knowledge Management: a Strategic Agenda. Long Range Planning, Vol. 30, 3, pp. 385-391.

Ramanathan Narayanan, Richardson, S. \& Abdul Latif Salleh. (2003). Knowledge Management: A Malaysian Study. Malaysian Management Review, Vol. 38, 1, pp. 79-89

Reich, R. (1991). The wealth of nations: Preparing ourselves for $21^{\text {st }}$ century capitalism. Simon \& Schuster, London.

Robbins, S.P. (2005). Organizational Behavior. Pear Prentice Hall: New Jersey

Roscoe, J.T. (1995). Fundamental research statistics for the behavioral science. Holt, Rinehart \& Winston, New York.

Rumesh Kumar. (2003). Managing knowledge in turbulent business environments: an empirical study in the Malaysian context. Malaysian Management Review, Vol. 38, 2, pp. 39-60.

Salisbury, M. (2001). An example of managing the knowledge creation process for a small work group. Management learning, Vol. 32, 3, pp. 305-319.

Salleh Yahya, Lailawati Mohd Salleh \& Goh, W. K. (2001). Human resource management practices \& knowledge management. Malaysian Management Review, Vol. 36, 1, pp. 33-39.

Saunders, M., Lewis, P. \& Thornhill, A. (2003). Research Methods for Business Students. Prentice Hall.

Sekaran,U. (1992). Research Methods for Business: A skill-building approach ( $2^{\text {nd }}$ edition). John Wiley \& Son: New York.

Senge, P. (1990a). The fifth discipline: The Art \& Practice of the Learning Organization. Doubleday: New York.

Senge, P. (1990b). The Leader's New work: Building Learning Organizations. Sloan Management Review, Vol. 32,1, pp.7-23.

Senge, P. (1992). Building Learning Organizations. The Journal for quality \& Participation, Vol. 15, 2.

Senge, P. (1999). It's the learning: The real lesson of the quality movement. The Journal for Quality \& Participation, Vol. 22, 6, pp. 34-40.

Slater, S.F. (1996). The challenge of sustaining competitive advantage. Industrial Marketing Management, Vol. 25, pp. $79-86$.

SMIDEC. (2009a). Corporate Information. [Online] Available: http://www.smidec.gov.my/detailpage.jsp?page=aboutus (June 2, 2009)

SMIDEC. (2009b). Strategic Planning. http://www.smidec.gov.my/detailpage.jsp?page=division2 (June 2, 2009)

Snyman, R. \& Kruger, C.J. (2004). The interdependency between strategic management \& strategic management \& strategic knowledge management. Journal of Knowledge Management, Vol.8, 1, pp. 5-19. 
Spender, J. C. (1996). Making knowledge the basis of a dynamic theory of the firm. Strategic Management Journal, Vol. 17, pp. 45-62.

Spraggon, M. \& Bodolica, V. (2008). Knowledge creation processes in small innovative hi-tech firms. Management Research News, Vol. 31, 11, pp. 879-894.

Stein, E. W. \& Zwass, V. (1995). Actualizing Organizational Memory with Information Systems. Information Systems Research, Vol. 6, 2, pp. 85-117.

Sviokla, J. J. (1996). Knowledge workers \& radically new technology. Sloan Management Review, pp. 25-40.

Tan, L. P. (2004). Knowledge Management in 25 award winning Malaysian companies. Malaysian Management Review, Vol. 39, 1, pp. 43-55

The Star. (2009). Smidec rebr\&ed as SME Corp Malaysia, July 10.

The Star. (2009). Redefining nation's growth model, September 14.

The Star. (2010). Towards an innovation economy, January, 16.

Treasury. (2009). The 2010 Budget Speech. [Online] Available: http://www2.treasury.gov.my/data/speech/bs10.pdf (23 October 2009)

Tsoukas, H. \& Vladimirou, E. (2001). What is organizational knowledge. Journal of Management Studies, Vol. 38, 7, pp. 973-993.

Van Maanen, J. (2006). Ethnography then \& now, Qualitative Research in Organizations \& Management. An International Journal, Vol. 1, 1, pp.13-21.

Wenger, E. C. \& Snyder, W. M. (2000). Communities of Practice: The organizational frontier. Harvard Business Review, Jan-Feb, pp. 139-145.

Wiig, K.M. (1997). Knowledge management: Where did it come from \& where will it go? Expert Systems With Applications, Vol.13,1, pp. 1-14.

Woodman, R.W., Sawyer, J.E. \& Griffin, R.W. (1993). Toward a theory of organizational creativity. Academy of Management Review, Vol. 18, 2, pp. 293-321.

Zikmund, W. G. (1994). Business Research Methods (4 ${ }^{\text {th }}$ Edition). The Dryden Press: Orlando.

Table 1. Detailed definition of Malaysian SMEs

\begin{tabular}{|c|c|c|c|}
\hline Category & Micro enterprise & Small enterprise & Medium enterprise \\
\hline $\begin{array}{l}\text { Manufacturing, } \\
\text { Manufacturing-related services } \\
\text { \& agro-based industries }\end{array}$ & $\begin{array}{l}\text { Sales turnover of } \\
\text { less than RM } \\
250,000 \text { OR } \\
\text { Full-time employees } \\
\text { less than } 5\end{array}$ & $\begin{array}{l}\text { Sales turnover between } \\
\text { RM } 250,000 \& \text { RM } 10 \\
\text { million OR } \\
\text { Full-time employees } \\
\text { between } 5 \text { to } 50\end{array}$ & $\begin{array}{l}\text { Sales turnover between } \\
\text { RM } 10 \text { million and RM } 25 \\
\text { million OR } \\
\text { Full-time employees } \\
\text { between } 51 \text { to } 150\end{array}$ \\
\hline $\begin{array}{l}\text { Services, } \\
\text { primary agriculture \& ICT }\end{array}$ & $\begin{array}{l}\text { Sales turnover of } \\
\text { less than RM 200,00 } \\
\text { OR } \\
\text { Full-time employees } \\
\text { fewer than } 5\end{array}$ & $\begin{array}{l}\text { Sales turnover between } \\
\text { RM } 200,000 \text { and RM } 1 \\
\text { million OR } \\
\text { Full-time employees } \\
\text { between } 5 \text { to } 19\end{array}$ & $\begin{array}{l}\text { Sales turnover between } \\
\text { RM } 1 \text { million and RM } 5 \\
\text { million OR } \\
\text { Full-time employees } \\
\text { between } 20 \text { to } 50\end{array}$ \\
\hline
\end{tabular}

Table 2. Internal Reliabilities for the scale

\begin{tabular}{|l|l|}
\hline Scale & Cronbach's alpha $(\boldsymbol{\alpha})$ \\
\hline Learning & $\mathbf{. 6 5 4}$ \\
\hline T-Shaped skills & $\mathbf{. 7 6 4}$ \\
\hline Organizational creativity & $\mathbf{. 8 9 7}$ \\
\hline Organizational performance & $\mathbf{. 8 3 8}$ \\
\hline
\end{tabular}


Table 3. Loading factor for learning

\begin{tabular}{|l|l|}
\hline Item & Factor Loading \\
\hline LEA1 & $\mathbf{. 6 5 8}$ \\
\hline LEA3 & $\mathbf{. 7 2 3}$ \\
\hline LEA4 & $\mathbf{. 7 7 0}$ \\
\hline LEA5 & $\mathbf{. 7 1 9}$ \\
\hline
\end{tabular}

Table 4. Loading factor for T-Shaped skills

\begin{tabular}{|l|l|}
\hline Item & Factor Loading \\
\hline TSS1 & $\mathbf{. 7 8 4}$ \\
\hline TSS2 & $\mathbf{. 5 5 1}$ \\
\hline TSS3 & $\mathbf{. 7 9 2}$ \\
\hline TSS4 & $\mathbf{. 7 3 3}$ \\
\hline TSS5 & $\mathbf{. 7 2 9}$ \\
\hline
\end{tabular}

Table 5. Loading factors for Knowledge Creation Process (Socialization, Externalization, Combination, and Internalization)

\begin{tabular}{|c|c|c|c|c|c|}
\hline & Factor Loading & 1 & 2 & 3 & 4 \\
\hline $\mathrm{KCS} 1$ & .632 & .111 & .236 & .632 & .016 \\
\hline $\mathrm{KCS} 2$ & .807 & .144 & .191 & .807 & .039 \\
\hline KCS3 & .600 & -.155 & -.022 & .600 & .419 \\
\hline $\mathrm{KCS} 4$ & .616 & .317 & -.053 & .616 & .317 \\
\hline KCS5 & .631 & .339 & .220 & .631 & .219 \\
\hline KCE1 & .572 & -.021 & .471 & .222 & .572 \\
\hline KCE2 & .678 & -.003 & .254 & .262 & .678 \\
\hline KCE3 & .612 & .309 & .008 & .358 & .612 \\
\hline KCE4 & .585 & .190 & .514 & .060 & .585 \\
\hline KCE5 & .626 & .211 & .076 & .015 & .626 \\
\hline $\mathrm{KCC} 1$ & .493 & .493 & -.056 & .302 & .228 \\
\hline $\mathrm{KCC} 2$ & .743 & .743 & -.007 & .259 & -.207 \\
\hline KCC3 & .580 & .580 & .399 & .080 & .137 \\
\hline $\mathrm{KCC} 4$ & .671 & .671 & .293 & .050 & .158 \\
\hline KCC5 & .712 & .712 & .083 & .045 & .354 \\
\hline KCI1 & .728 & .124 & .728 & .075 & .305 \\
\hline $\mathrm{KCI} 2$ & .778 & .131 & .778 & .078 & .165 \\
\hline $\mathrm{KCI} 3$ & .665 & .191 & .665 & .253 & -.048 \\
\hline KCI4 & .421 & .593 & .421 & .096 & .062 \\
\hline
\end{tabular}


Table 6. Loading factor for Organizational Creativity

\begin{tabular}{|l|l|}
\hline Item & Factor Loading \\
\hline OC1 & $\mathbf{. 8 5 7}$ \\
\hline OC2 & $\mathbf{. 8 4 7}$ \\
\hline OC3 & $\mathbf{. 7 9 8}$ \\
\hline OC4 & $\mathbf{. 8 3 7}$ \\
\hline OC5 & $\mathbf{. 8 8 3}$ \\
\hline
\end{tabular}

Table 7. Loading Factor for Organizational Performance

\begin{tabular}{|l|l|}
\hline Item & Factor Loading \\
\hline OP1 & $\mathbf{. 6 6 9}$ \\
\hline OP2 & $\mathbf{. 7 8 0}$ \\
\hline OP3 & $\mathbf{. 7 8 1}$ \\
\hline OP4 & $\mathbf{. 8 2 3}$ \\
\hline OP5 & $\mathbf{. 8 4 1}$ \\
\hline
\end{tabular}

Table 8. Results of Regression Analysis for Learning vs. the knowledge creation process

\begin{tabular}{|l|l|l|l|l|l|l|}
\hline IV & DV & R2 & F & B & t & Sig \\
\hline LEA & KCP & 0.213 & 27.911 & 0.462 & 5.283 & 0.001 \\
\hline
\end{tabular}

Table 9. Results of Regression Analysis for T-Shaped skills vs. The knowledge creation process

\begin{tabular}{|l|l|l|l|l|l|l|}
\hline IV & DV & R2 & F & B & t & Sig \\
\hline TSS & KCP & 0.304 & 45.039 & 0.552 & 6.711 & 0.001 \\
\hline
\end{tabular}

Table 10. Results of Regression Analysis for the knowledge creation process (KCP) vs. organizational creativity (OC)

\begin{tabular}{|l|l|l|l|l|l|l|}
\hline IV & DV & R2 & F & B & t & Sig \\
\hline KCP & OC & 0.296 & 43.254 & 0.544 & 6.577 & 0.001 \\
\hline
\end{tabular}

Table 11. Results of Regression Analysis for Organizational Creativity (OC) vs. Organizational Performance (OP)

\begin{tabular}{|l|l|l|l|l|l|l|}
\hline IV & DV & R2 & F & B & t & Sig \\
\hline OC & OP & 0.334 & 51.542 & 0.578 & 7.179 & 0.001 \\
\hline
\end{tabular}

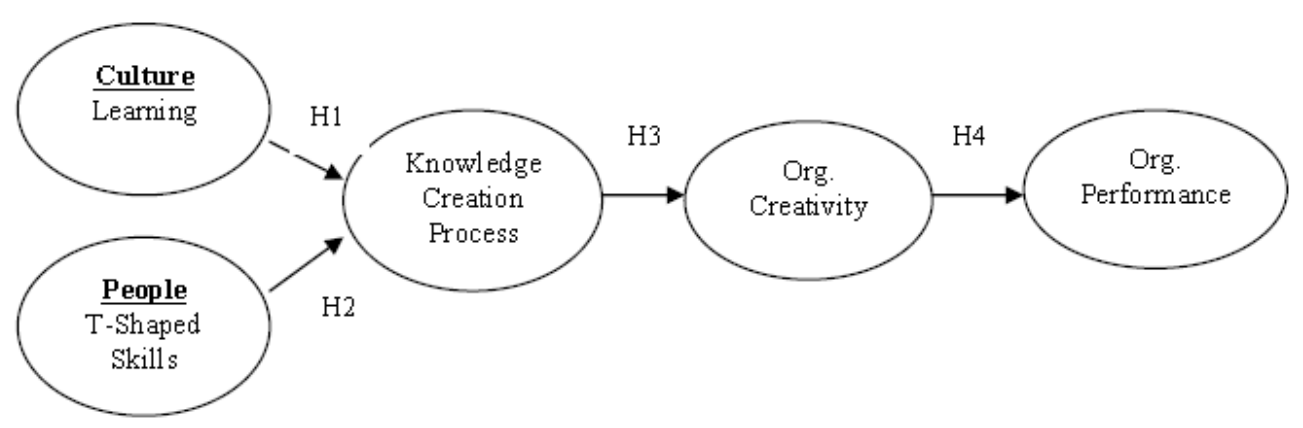

Figure 1. Theoretical Framework 